\title{
Are There Excellent Service Firms, and Do They Perform Well?
}

\author{
ALBERT CARUANA, LEYLAND F. PITT \\ and MICHAEL H. MORRIS
}

While the construct of business excellence, as defined in the very successful book by Peters and Waterman, had a marked influence on managers in the 1980s, and in all likelihood in the 1990s, it met with some scepticism in academic circles. This was because the construct as conceptualised did not meet the more rigorous requirements of reliability and validity established by critical researchers, and also because many of the so-called excellent firms later showed themselves to be rather ordinary performers at best. Recently, an apparently successful instrument to measure the original Peters and Waterman excellence construct named EXCEL has been developed by Sharma et al., in the United States. In this article the authors describe the use of EXCEL in a sample of large UK service firms and comment on its reliability and validity. Links are also established between excellence and overall business performance in these firms.

\section{INTRODUCTION}

There would be little doubt that in a polling of the many clichés current in the 'management-speak' of the 1980s, 'excellence' would have been a frontrunner. Firms strove 'for excellence', to 'achieve excellence', and to 'sustain excellence'. Managers exhorted their subordinates to 'be excellent', and many expended considerable resources on consultants and experts, conferences, seminars, books, audio- and videotapes in search of the holy grail. The interest in 'excellence' owes much to the work of Peters and Waterman [1982] in their best-selling book, In Search of Excellence, and there are few endeavours which permeated the thinking of practising managers in the $1980 \mathrm{~s}$ as much as this work. Written as it is, in an informal style with obvious appeal to practising managers, it has enjoyed considerable influence among this

\footnotetext{
Albent Caruana is in the Department of Management, University of Malta, Msida, Malta. Leyland F. Pitt is at Henley Management College, Greenlands, Henley on Thames, RG9 3AU, UK. Michael H. Morris is in the School of Business and Public Administration, Stockton, California, USA.
} 
audience. The excellence studies met with considerable reservation in academic circles, however.

Peters and Waterman [1982] assessed a sample of 62 US companies on three criteria as follows:

1. Large size (which meant annual sales of [with few exceptions] one billion US dollars, over the 20-year period 1961-80).

2. Sustained financial performance - this considered six aspects:

- three related to profit (return on capital, return on equity, return on sales);

- two related to growth (compound asset growth, compound equity growth);

- one related to market evaluation (average rate of market value to book value).

To qualify on these criteria, a company had to be in the top half of its industry in at least four of the six measures over the full 20 year period'.

3. Innovative capability was seen to consist not only of a company's ability to come up with a flow of new marketable products and services, but also how rapidly and skilfully it responded to what was happening in its environment. Again, this capability had to be visible over the entire 20-year period. This assessment was delegated to 'selected industry experts'.

On the basis of the above criteria, 43 out of the 62 companies in the sample were classified as excellent. A 25-year literature review as well as interviews with top executives were used to analyse these 43 companies. Based mostly on this sample, Peters and Waterman [1982] identified eight organisational design attributes that they assert distinguish excellent companies, the characteristics of which, form the basis of the book:

1. A bias for action - getting on with it and overcoming the inertia that often comes with size.

2. Close to the customer - understanding the needs of 'lead' users and providing the desired levels of service, quality and reliability.

3. Autonomy and entrepreneurship - devolution, providing space and support for creative ideas that lead to innovative product and service launches.

4. Productivity through people - people are seen as the primary source of productivity gains.

5. Hands on, value driven - the organisation's values result in a distinct and binding culture which gives direction to action by all members.

6. Stick to the knitting - concentration on and development of the organisation's areas of distinctive competence.

7. Simple form. lean staff - simple organisation structures, with efficient management supported by small staff teams. 
8. Simultaneous loose-tight properties - an effective balance between central diréction and individual authority.

\section{Academic Criticism of the 'Excellence' Work}

In a critical review, Carroll [1983] disagrees with the narrow definition of excellence used, and suggests that excellence depends not only on the eight attributes, or what he calls 'management effectiveness', but also on several 'non-management' variables which include technology, finance, raw materials, and government policy. Other empirical work has also examined the excellence study, questioned the results and prescriptions, and even disputed the construct /Aupperle, Acar and Booth, 1986; Chakravarthy, 1986; Hitt and Ireland, 1987; Johnson, Natarajan and Rappaport, 1985; Ramanujam and Venkatraman, 1988]. In their review of this literature, Sharma, Netemeyer, and Mahajan [1990] draw four general conclusions:

- All authors have tended to indicate what they believe is a better measure of pertormance and 'have then proceeded to see how Peters and Watermans' excellent companies compare to this 'better' measure(s) of performance. This procedure is perhaps best exemplified in the work of Aupperle, Acar and Booth [1986].

- Excellence should be seen as the extreme (and perhaps even infinitely unattainable) point on a continuum. Yet there is a tendency among authors for a rigid dichotomous classification of excellent firms, i.e. excellent/not excellent, as for example reflected in the work of Clayman [1987] and, more recently, Langbert [1990].

- Studies tended to focus on single item measures. Doyle [1992] points out that seeking excellence on one dimension only results in meeting the needs of one group over that of others, with resulting disequilibrium. Managers should therefore not seek to excel only on a single objective, but rather look for a balanced performance over time on a set of goals. In a survey of over 1700 UK executives Barsoux [1989] also sees excellence as multidimensional.

- Measures that have been used to date have not been rigorously developed to operationalise the eight attributes of excellence of Peters and Waterman. Capon, Farley, Hulbert and Lei [1991], apparently unaware of the work by Sharma et al., did develop a rigorous measuring instrument aimed at operationalising Peters and Watermans' eight attributes of excellence. Their conclusion is that superior financial performance and innovation (and therefore excellence) are not influenced solely by Peters and Waterman's eight 'organisational' variables, but also by 'strategy' variables. One of the major problems of the study is that the items to operationalise the eight attributes 
of Peters and Waterman [1982] 'were assembled from a set of items collected for other purposes'. However the EXCEL scale developed by Sharma et al. was designed specifically to measure excellence based on the eight variables of Peters and Waterman [1982]. This instrument has been rigorously assembled following the procedures as outlined by Churchill [1979] for the development of marketing constructs. The authors report an alpha coefficient [Cronbach, 1951] of .89 and the existence of content and convergent validity.

Much of the criticism levelled at the excellence studies and the construct in general, by the various authors, which has been briefly reviewed above, is substantial. However, it is the development of EXCEL by Sharma et al. that provides the researcher with the greatest possibility thus far identified of testing the Peters and Waterman paradigm. Thus, if following the administration of EXCEL companies are shown to possess the eight variables identified by Peters and Waterman [1982], it can be concluded that these are excellent according to the 'In Search of Excellence' definition. Following Peters and Waterman [1982], such excellent companies should achieve on all three criteria; size, performance and innovation. The performance of companies identified as excellent can be also be measured. If the Peters and Waterman excellence paradigm is to hold, such companies should stand the authors' own test and their performance should be 'in the top half of the industry in at least four of the six (performance) measures' which Peters and Waterman themselves use. An obvious research proposition is therefore:

- $\mathrm{P}_{1}$ There is a positive relationship between excellence and company performance in (service) firms.

In this article we transplant the excellence construct across national boundaries, to test its general validity in another country and culture. As the 'excellence' studies only contained a relatively small proportion of service firms, it might be suggested that these were under-represented. Here, therefore, we concentrate on excellence in service firms, suggesting that the unique characteristics of services, as opposed to products - namely intangibility, simultaneous production and consumption, heterogeneity, and perishability [Berry and Parasuraman. 19911-might have an impact. We begin by describing a study of excellence and performance in British service firms. We then consider the reliability and validity of the EXCEL instrument across national boundaries. Next, an attempt is made to link excellence in service firms to their performance. Finally implications of the study are discussed, and directions for possible future research identified. 


\section{The Study}

To be able to investigate the relationship between excellence and business performance two measuring instruments were used. The 16 item, 7 point, Likert-type, instrument developed by Sharma et al. [1990] was utilised to measure excellence. To measure performance it was thought impractical to expect busy top managers to collect actual performance data, even if they were agreeable to divulging such information. Obtaining such data from documentary sources, such as trade and other publications, was not seen to be a viable alternative. Dess and Robinson [1984], who looked at the accuracy of such data, hold that it is of minimal use in explaining variation in performance between firms and recommend that researchers consider using subjective perceptual measures of organisation performance. Pearce, Robbins and Robinson [1987] show that such subjective evaluations are reliable means for measuring performance. Therefore, to measure performance, three, five point, Likert type, items were used. Two of these sought to measure ROCE and Sales growth of the respondent's firm, in the last five years, relative to other companies in the industry; while the third item asked respondents for their impression of their firm's overall performance, in the last five years, relative to others in their industry. Finally a further question related to management's overall perception of the excellence of their company was added.

1,000 postal questionnaires were mailed to the largest (by number of employees in the last three years) British service based firms, as identified from the 7,566 service firms listed on the FAME CD-ROM database as at the end of October 1993. A covering letter addressed to the Marketing Director was sent with each questionnaire, together with a return postage paid envelope. Fifty questionnaires were returned mostly because of incorrect addresses while three respondents refused to participate principally 'as a matter of policy' not to reply to questionnaires. These were excluded, leaving a base of 950 firms. By the cut-off date, three weeks later, a 13.8 per cent response rate was recorded. This response rate is in line with present UK response rates to postal surveys addressed to senior management 'positions' when no pre-notification or follow-up calls are used.

Results

In this part of the study we replicate the work of Sharma, Netemeyer and Mahajan [1990] in their development of EXCEL. The scale can be summarised by looking at the characteristics of the individual items, those of the overall scale, and the relationships between the individual items and the entire scale. Table 1 shows the means and standard deviations for the individual items in the scale, and for the overall scale (a summation of the individual items). The average scores are all high and range from 4.70 for item 
14 to 5.89 for item 15. At 1.64, item 3 has the largest standard deviation. The average score for the full EXCEL instrument is 81.35 with a standard deviation of 15.36 .

TABLE 1

DESCRIPTIVE STATISTICS FOR THE EXCEI. SCALE

Item

I. In this organisation we encourage employees to develop new ideas.

2. This organisation has a small staff that delegates authority efficiently.

3. It is the belief of top management in this organisation that its people are of utmost importance to the company.

4. In this organisation we instil a value system in all our employees.

5. We provide personalised attention to all our customers.

6. In this organisation top management creates an atmosphere that encourages creativity and innovativeness.

7. The company's values are the driving force behind our operation.

8. This firm is flexible and quick to respond to problems.

9. This company concentrates in product areas where it has a high level of skill and expertise.

10. We have a small, but efficient management team.

11. This company develops products that are natural extensions of its product line.

12. This organisation truly believes in its people.

13. This company considers after-the-sale service just as important as making the sale itself.

14. This company believes in experimenting with new products and ideas.

15. The company believes that listening to what customers have to say is a good skill to have.

16. This organisation is flexible with employees but administers discipline when necessary.

Full EXCEL Scale

Scale with 2 items eliminated

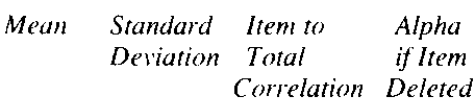

$\begin{array}{llll}5.0611 & 1.3229 & .7157 & .9149\end{array}$

$\begin{array}{llll}4.4733 & 1.4588 & .6158 & .9180\end{array}$

$\begin{array}{llll}5.5725 & 1.6363 & .7285 & .9141\end{array}$

$\begin{array}{llll}4.7328 & 1.4509 & .6521 & 9168\end{array}$

$\begin{array}{llll}5.0229 & 1.3893 & .5149 & .9212\end{array}$

$\begin{array}{llll}4.4733 & 1.5208 & .7988 & .9115\end{array}$

$\begin{array}{llll}4.7634 & 1.5681 & .6811 & .9158\end{array}$

$\begin{array}{llll}4.9618 & 1.4433 & .6577 & .9166\end{array}$

$5.7863 \quad 1.3186 \quad$ Deleted Deleted

$\begin{array}{llll}4.9695 & 1.5833 & .6555 & .9168\end{array}$

$5.2061 \quad 1.2933$ Deleted Deleted

$\begin{array}{llll}5.0000 & 1.5738 & .8146 & .9108\end{array}$

$\begin{array}{llll}5.5038 & 1.4378 & .5342 & .9207\end{array}$

$\begin{array}{llll}4.7023 & 1.3284 & .5317 & .9206\end{array}$

$\begin{array}{llll}5.8855 & 1.0425 & .6139 & .9187\end{array}$

$\begin{array}{llll}5.2366 & 1.2205 & .5855 & .9190\end{array}$

$81.3 .51 \quad 15.360$

$\begin{array}{ll}70.358 & 14.175\end{array}$ 
The relationship between individual items and the composite score is shown under the Item-Total Statistics heading, also in Table 1. The corrected itemtotal correlation is the Pearson correlation coefficient which indicates the strength of the relationship between the score of individual items and the other items. 'When items predominantly correlate positively with one another, those with the highest average correlation are the best items' [Nunnally, 1978: 279]. Items 9 and 11 , at 0.47 and 0.39 respectively, are below the acceptable rule of thumb of 0.50 . Moreover, the squared multiple correlation which shows the degree that the observed variability in the response to an item can be explained by the other items in the scale is low for both items 9 and 11. These two items asked respondents whether their company 'concentrates in product areas where it has a high level of skills and expertise', and whether their firm 'develops products that are natural extensions of its product line'. Both questions are 'product' related and from the comments made next to these two questions by respondents it is clear that some of them did not see their firms as having 'products'. One respondent who identified himself as a 'contractor' noted that they did not have a 'fixed' product. Although EXCEL was not specifically developed with service based companies in mind it will be shown that when these two items are eliminated a factor analysis provides useful results.

\section{INSTRUMENT RELIABILITY}

The alpha coefficient [Cronbach, 1951] for EXCEL is 0.9209 , and 0.9224 when items 9 and 11 are eliminated (see Table 1). These alpha scores are higher than those obtained by Sharma et al. [1990] who report an alpha score of 0.89 and 0.90 . What is an acceptable level of reliability depends on what the instrument will be used to measure. Nunnally [1978: 245] holds that for 'hypothesised measures of a construct, one saves time and energy by working with instruments that have only modest reliability, for which purpose reliabilities of 0.70 or higher will suffice'. It is important to ensure that the high coefficient alpha score obtained is not simply the result of the instrument having a large number of items. To do this the standardised item alpha has been computed. At 0.9199 versus 0.9223 , the result obtained does not differ significantly from the alpha coefficient thereby confirming the reliability of the instrument.

\section{Factor Analysis}

The number of factors that were to be extracted needed to be determined. This required consideration of a number of aspects which included prior criteria, the maximum percentage of variance extracted and the latent root criteria. The last was the principal consideration as it is one of the most widely used. 
Although Kaiser [1974] provides several reasons for its success, Kim and Mueller [1978: 43] hold that 'its acceptance is still based on heuristic and practical grounds'. This is because only factors having eigenvalues greater than 1 are considered significant while latent roots less than 1 are considered insignificant and discarded. The rationale for the latent root criteria is that any individual factor should account for at least the variance of a single variable if it is retained for interpretation. The principal component (PC) method of factor extraction was used. One of the major advantages of using the PC method is 'that each principal component factor explains more variance than would the loadings obtained from any other method of factoring' [Nunnally, 1978: 357]. When items 9 and 11 were eliminated, a two factor solution resulted which accounted for 59.4 of the cumulative percentage of variance. This was followed by a varimax rotation. The varimax rotation is one of the most widely used. The strength of the Principal Components plus Varimax rotation is underlined by Nunnally [1978: 385] who holds that, 'When an investigator is dissatisfied with the PC plus Varimax solution, usually it is because no simple, clear factor solution could be obtained by any other method.' When items 9 and 11 were eliminated an acceptable two factor solution resulted, from the PC plus Varimax rotation as can be seen from Table 2.

TABLE 2

FACTOR MATRIX AFTER A VARIMAX ROTATION

\begin{tabular}{lll} 
ITEM & Factor $/$ & Facfor 2 \\
1 & .74017 & .27819 \\
2 & .65664 & .22499 \\
3 & .70230 & .35577 \\
4 & .57758 & .41501 \\
5 & .11835 & .85865 \\
6 & .81531 & .29422 \\
7 & .61218 & .41180 \\
8 & .57616 & .41328 \\
9 & \multicolumn{2}{c}{ Deleted } \\
10 & .72580 & .19065 \\
11 & \multicolumn{2}{c}{ Deleted } \\
12 & .76597 & .39007 \\
13 & .17049 & .81889 \\
14 & .42834 & .42624 \\
15 & .41384 & .58639 \\
16 & .80270 & -.03345
\end{tabular}

Scores and Factor Names

Items 5, 13 and 15, which load onto Factor 2, are the three items that capture the attribute referred to by Peters and Waterman [1982] as 'Close to the customer'. It also seems clear that Factor 1 represents a general factor as 
hypothesised by Sharma et al. [1990]. Factor scores, which are used for subsequent analysis, were generated and factor names were given as follows:

\begin{tabular}{lcl} 
& Labels for factor scores & \multicolumn{1}{c}{ Factor names } \\
Factor 1 & FAC $1 \mathrm{E}$ & General excellence factor \\
Factor 2 & FAC2E & Close to the customer
\end{tabular}

\section{CONTENT VALIDITY}

Assessing the content validity of a scale is necessarily qualitative rather than quantitative. It involves two aspects: the thoroughness with which the construct to be scaled and its domain were explicated; and the extent to which the scale items represent the constructs' domain [Parasuraman, Zeithaml and Berry, 1988]. The procedures that should be followed in the development of psychometric scales for use in the measurement of marketing constructs have been outlined by Churchill [1979]. This approach has been followed by Sharma et al. [1990] in the development of their instrument. Qualitative support is further provided from the data in Table 3 which shows the mean score for respondents under each dimension grouped by their overall impression of the excellence of their organisation. This increases for each factor as the overall score increases.

TABLE 3

EXTRACTED FACTOR SCORES WITH RESPONDENTS' OVERALL. SCORE FOR THEIR FIRM'S EXCELLENCE

Response to Question: 'This organisation exhibits high levels of business excellence'.

Agree Strongly

Strongly

Overall score 12

FACIE

FAC2E

Number of

responses

$\begin{array}{cc}1 & 2 \\ 2.0000 & 3.3737 \\ 3.6666 & 4.6296\end{array}$

$3.6666 \quad 4.6296$

3
4.4132
4.6997

2

9

11

21

$\begin{array}{ccc} & & \begin{array}{c}\text { Strongly } \\ \text { Disagree } \\ 7\end{array} \\ 5 & 6 & 7 \\ 5.0006 & 5.3485 & 5.5046 \\ 5.4479 & 5.7407 & 6.2833 \\ 32 & 36 & 20\end{array}$

\section{MULTIPLE REGRESSION ANALYSIS}

A number of multiple regression procedures were conducted, firstly to confirm the convergent validity of the EXCEL scale, and then to determine the nature of the relationship between the two extracted EXCEL factors and the various measures of performance. Each of the three measures on the performance scale were regressed against the extracted factors of excellence. A further factor analysis of the three performance items confirmed the existence of a single factor which accounted for 70 per cent of the variance in the three items. 
This general factor of business performance - called the performance factor as opposed to the overall performance item - was also regressed against the extracted factors. Furthermore, the three item scale showed an alpha coefficient of 0.76 indicating that the three items were capturing overall performance. The regression procedures are summarised for the sake of convenience, simplicity, and brevity in Table 4 . Table 4 reports the results of five multiple regression procedures, by referring to the dependent variable in each case; the $\mathrm{R}^{2}$ for the regression; the $\mathrm{F}$ value for the analysis of variance procedure for the full regression; the B's for each of the two factors of excellence extracted; the constant term in the regression; and, the T scores for the factors as variables in the regression equation.

TABLE 4

CONVERGENT VALIDITY OF EXCELL, AND EFFECTS OF 2 EXCELLENCE FACTORS ON FOUR MEASURES OF PERFORMANCE IN SERVICE FIRMS: MULTIPLE REGRESSION ANALYSES

$\begin{array}{lccccccc}\text { Dependent Variable } & \text { R2 } & \begin{array}{l}\text { Analysis of } \\ \text { Variance } \\ (F)\end{array} & \begin{array}{c}\text { FACIE } \\ \text { B }\end{array} & \begin{array}{c}\text { FAC2E } \\ \text { B }\end{array} & \begin{array}{c}\text { FAC1E } \\ \text { T }\end{array} & \begin{array}{c}\text { FAC2E } \\ \text { T }\end{array} & \begin{array}{c}\text { Constant T } \\ \text { B }\end{array} \\ \begin{array}{l}\text { Overall Impression } \\ \quad \text { of Excellence }\end{array} & .35 & 34.93 & .66 & .59 & 6.21 & 5.60 & 4.98 \\ \begin{array}{l}\text { Overall Performance } \\ \quad \text { Item }\end{array} & .15 & 11.04 & .25 & .25 & 3.34 & 3.30 & 3.89 \\ \text { ROCE } & .04 & 2.65^{*} & .16 & .12 & 1.84^{*} & 1.38^{*} & 3.49 \\ \text { Sales Growth } & .13 & 10.18 & .25 & .23 & 3.28 & 3.09 & 3.60 \\ \text { Performance Factor } & .14 & 10.74 & .28 & .26 & 3.41 & 3.14 & 5.14\end{array}$

$*=$ not significant at $\mathrm{p}<0.05$. All other $\mathrm{F}$ and $\mathrm{T}$ scores significant at $\mathrm{p}<0.01$

Convergent Validity. Evidence of the convergent validity of a measure is provided by the extent to which it correlates highly with other methods designed to measure the same construct [Churchill, 1979]. Regression of the two factors identified in EXCEL with a measure of the overall impression of management's' perception of the excellence of their organisation shows an $\mathrm{R}^{2}=0.35$ significant at the $p<0.01$ level. It can be seen from Table 4 that both extracted factors are significant.

- Excellence and the overall performance item.

The regression of the dimension of excellence on overall performance against competitors, shows an $\mathrm{R}^{2}=0.15$ which is significant at $\mathrm{p}<0.01$. Overall performance does appear to be related in a significant, albeit small way, to the excellence of service firms. The significance of the $t$ score indicates both extracted factors to be important in this. 
- Excellence and the ROCE item.

The regression of the dimension of excellence on ROCE, shows no significant relationship, with $\mathrm{R}^{2}=0.04$ which is not significant at the $\mathrm{p}<0.05$. Respondents' perceptions of relative ROCE does not seem to be affected by the excellence of service firms. The $t$ scores of the variables in the regression equation indicate that neither of the two dimensions of excellence are significant. ROCE was one of the six ratios used by Peters and Waterman to determine who were the excellent companies.

- Excellence and the sales growth item.

The regression of the dimension of excellence on sales growth, shows an $\mathrm{R}^{2}=0.13$ which is significant at the $\mathrm{p}<0.01$. Respondent's perception of relative sales growth over the last five years do seem to be linked to the excellence of these firms. The $t$ scores of the variables in the regression equation indicate both dimensions to be significant. Sales growth was another of the six ratios used by Peters and Waterman in determining who were the excellent firms.

\section{- Excellence and the overall performance factor.}

Table 4 shows that there is a significant relationship between excellence and the overall (i.e. combined) performance factor, with $R^{2}=0.14$, significant at $\mathrm{p}<0.01$. The $t$ scores for the variables in the regression equation show that both the 'General factor' and the 'Close to the customer' factors are important.

\section{CONCLUSION}

The performance results reported above provide support for the hypothesis of this study that a service company's excellence is related positively to business performance. What is also interesting is the emergence of the "Close to the Customer' dimension - one of the eight attributes identified by Peters and Waterman [1982] as a distinct and separate dimension, while all the other seven attributes load together under a 'General factor'. Market orientation has been expressed in such terms as 'close to the customer' [Webster. 1988; Shapiro, 1988]. This seems to suggest a strong link between the excellence construct and market orientation, at least in the case of the larger British service based firms. The study may also be of benefit to practising managers in the service sector. The reported mean scores can provide a benchmark for managers to assess the degree of excellence of their companies relative to the larger British service firms.

Obviously, the findings reported must be evaluated in the light of certain limitations. These include the possible presence of non-response bias 
associated with postal questionnaires; the use of self-reported performance measures; and the fact that the population consisted of the larger British service companies which means that any generalisations of findings to other populations must be made with extreme caution. There are opportunities for further research. The availability of EXCEL enables the study of the effects of excellence, as conceptualised by Peters and Waterman, on other variables, such as: innovation and new product development; complaint handling; and levels of market orientation.

The statistical reliability claimed for EXCEL by the developers has been confirmed in this study, as have both content and convergent validity. Some indication of external validity is also provided in this study by virtue of the fact that 'more excellent' service firms perform better. Nomological validity may be in some doubt however, as, rather than forming eight distinct characteristics of excellence, the factor analysis suggests that there may simply be two facets of excellence - the 'close to the customer' factor, and the 'general excellence' factor as outlined above. This may indeed be of more importance to practising services managers than at first appears, and of greater interest to them than to psychometricians and developers of measures of marketing constructs: all of the other seven facets of excellence collapse into one factor 'close to the customer' is unique. The other seven facets are internal, close to the customer is externally focused. The seven common facets have to do with structure, style, systems and values, which probably have to be in place before the organisation can really attempt to get 'close to the customer'.

Did the excellence studies, and the by-now-famous book, deserve the attention they received, and the discussion they still manage to engender? Does EXCEL capture the spirit and construct of excellence? Why do two clear factors emerge, and why is customer orientation out there on its own? Is excellence worth pursuing? It would be presumptuous to suggest that the work discussed here answers all these questions fully. It is hoped, however, that it does shed further light on these issues, and from the perspectives of another industry, another culture. While it might be verging on the tautological to propose that the excellence studies and the book deserved attention and discussion because a lot of attention and discussion was expended, this work did re-emphasise what many managers and observers of enterprise held to be common sense: create structures that empower and reward productive people, be really good at what you are best at, and pay as much attention to implementation as to creativity. Be as close to the customer as possible. Success will follow. Another tautology seems to flow: be excellent and success will follow naturally. What the work did achieve was to alert managers once more to the basics, by using dramatic stories from 'excellent' companies (then at least!) to illustrate what could be done and what would happen as a result in a way that, with all due respect, no academic journal could ever have done. So many of 
the excellent companies are no longer successful, or even around for that matter? Herein may perhaps lie the most valuable lesson of all to come from the excellence work: never rest on the laurels of excellence, but rather, reinvent the organisation as the game changes. Perhaps the excellence studies, while lacking in academic rigour, do have a strong message for managers after all.

\section{REFERENCES}

Aupperle, K.E., W. Acar and D.E. Booth, 1986, "An Empirical Critique of "In Search Of Excellence": How Excellent are the Excellent Companies?. Journal of Management. Vol. 12, No. 4, pp. 499-512.

Barsoux, J.L., 1989, 'Corporate Excellence in the UK: Who Dominates the Sectors, Multinational Business', The Economist Publication, 3 (Autumn), pp. 1-21.

Berry. L.L. and A. Parasuraman, 1991, Marketing Services-Competing ihrough Quality. New York: Free Press, Macmillan.

Capon, N., J.U. Farley, J.M. Hulbert and D. Lei, 1991, 'In Search of Excellence Ten Years Later: Strategy and Organisation Do Matter'. Management Derisions, Vol. 29, No. 4, pp. 12-21.

Carroll. D.T., 1983. 'A Disappointing Search for Excellence', Harvard Business Review (Nov.-Dec.). pp. 78-88.

Chakravarthy, B.S., 1986, 'Measuring Strategic Performance', Strategic Management Journal. Vol. 7 (Sept.-Oct.), pp. 437-58.

Churchill, G.A. Jr.. 1979, 'A Paradigm for Developing Better Measures of Marketing Constructs', Journal of Marketing Constructs', Journal of Marketing Research, Vol. XVI (Feb.), pp. $64-73$.

Clayman, M., 1987, 'In Search of Excellence: The Investor's Viewpoint'. Financial Analysis Journal, Vol. 43, No. 3 (May-June), pp. 54-63.

Cronbach, L.J., 1951, 'Coefficient Alpha and the Internal Structure of Tests, Psvchometrika. Vol. I6. No. 3 (Sept.), pp. 297-333.

Dess, G.G. and R.B. Robinson, 1984, 'Measuring Organizational Performance in the Absence of Objective Measures: The Case of the Privately-Held Firm and Conglomerate Business Unit', Strategic Management Journal, Vol. 5 (July-Sept.), pp. 265-73.

Doyle. P., 1992, 'What are the Excellent Companies?'. Journal of Marketing Management, Vol. 8. pp. $101-16$.

Hitt, M.A. and R.D. Ireland. 1987, Peters and Waterman Revisited: The Unended Quest for Excellent', Academy of Management Executive, Vol. I (May), pp. 91-8.

Johnson, B. A. Natarajam and A. Rappaport, 1985, 'Shareholders Returns and Corporate Excellent', Journal of Business Strategy, Vol. 6 (Fall), pp. 62-62.

Kaiser, H.F., 1974, 'An Index of Factorial Simplicity', Psychometrica, Vol. 39. pp. 31-6.

Kim, J. O. and C.W. Mueller, 1978, Factor Analysis: Statistical Method and Practical /ssues, Beverley Hills, California: Sage.

Langbert. M., 1990, 'In Search of Compensation: A Comparison of Executives in Peters and Waterman's Excellent and Fortunes Least Admired Firms', Benefits Quarterly. Vol. 6, No. 2. p. 23.

Nunnally, J.C.. 1978, Psychometric Theory, New York: McGraw Hill, 2nd ed.

Parasuraman, A.V V.A. Zeithaml and L.L. Berry, 1988, 'Servqual: A Multiple-Item Scale for Measuring Consumer Perceptions of Service Quality', Journal of Retailing, Vol. 64. No. 1 (Spring). pp. 12-40.

Pearce, J.A., D.K. Robbins and R.B. Robinson, 1987, 'The Impact of Grand Strategy and Planning Formality on Financial Performance', Strategic Management Journal, Vol. 8 (March-April). pp. 125-34.

Peters. T.J. and R.H. Waterman, 1982, In Search of Excellence, New York: Harper \& Row. 
Porter, M.E., 1990, 'The Competitive Advantage of Nations', Harvard Business Review (March-April), pp. 73-93.

Ramanujam, V. and N. Venkatraman, 1988, 'Excellence, Planning and Performance', Interfaces, Vol. 18 (May-June), pp. 23-31.

Shapiro, B.P., 1988, 'What the Hell is "Market Oriented"?', Harvard Business Review, Vol. 6 (Nov.-Dec.), pp. 119-25.

Sharma, S., R.G. Netemeyer and V. Mahajan, 1990, 'In Search of Excellence Revisited: An Empirical Evaluation of Peters and Waterman's Attributes of Excellence' in W.O. Bearden and A. Parasuraman (eds.), Enhancing Knowledge Development in Marketing, Vol. 1, Chicago: American Marketing Association, pp. 322-8.

Webster, F.E. Jr., 1988, 'The Rediscovery of the Marketing Concept', Business Horizons, Vol. 31. No. 3 (May-June), pp. 29-39. 
Copyright of Service Industries Journal is the property of Taylor \& Francis Ltd and its content may not be copied or emailed to multiple sites or posted to a listserv without the copyright holder's express written permission. However, users may print, download, or email articles for individual use. 